\title{
Exploring Health Technology Management Relevance to Safety and Quality in Hospital Care
}

\section{Narino $\mathrm{AH}^{*}$}

Director of Science and Innovation at Medical Sciences, University of Medical Sciences, Matanzas, Cuba

*Corresponding author: Arialys Hernandez Narino, PhD Director of Science and Innovation at the University of Medical Sciences, Central Highway, km 101, Matanzas, Cuba, Tel: 45295835;

Investigation Paper

Volume 4 Issue 2

Received Date: March 11, 2021

Published Date: April 07, 2021

DOI: $10.23880 /$ jqhe-16000215 Email: arialishn.mtz@infomed.sld.cu

\section{Abstract}

Technology management is a key issue for innovation and quality in health care sector, which, in turn, implies effectiveness and safety considerations. It is valuable, to explore the influence of technology to safety management and quality in health environment, and so to dig into what topics arise from this relationship. The purpose of this study is to explore the relevance of Health Technology Management to safety and quality in health organizations from health professional's perceptions and scientific evolution perspectives.

Methodology and Theoretical Orientation: An exploratory based qualitative study was conducted. A semi-structured interview was administered to health professionals with professional and academic experience in clinical settings in Matanzas territory. There were selected the main issues raised from professional's opinions. Additionally, there was examined the scientific development of this subject by means of a review of research documents published in Sciencedirect and Scielo databases.

Findings: Main views were similar as to technology use, assessment and innovation impact on human errors, how they may condition clinical and therapeutic practices, health recovery as well as a risky care environment for patients and personnel.

Conclusion \& Significance: It is confirmed the importance of health technology management to safety and quality of health care as well as research.

Keywords: Biomedical Technology; Management; Technology Assessment; Safety; Quality; Hospital Care

\section{Introduction}

Health technologies and medical equipment are considered essential factors for prevention, diagnosis, treatment and health rehabilitation [1].

Management and innovation of those technologies should be addressed through an integral approach; that means the combination of educational technologies for promotion and diseases prevention; the efficient and creative use and management of biomedical technologies together with the continuous improvement of health techniques and procedures based on systematic professional updating and the whole research cycle [2].

Providing a safe environment for patient is an 
important goal for proper health technology management. Cometto MC, et al. [3] they refer that patient safety implies the combination of standards, procedures, devices and methods which are based on research evidence, and they are aimed to minimize risks and adverse events. It also includes diagnostic and therapeutic practices, nursing care and environment measures, organizational performance, employee's competences and maintenance.

According to a report from World Health Organization (WHO) on quality of care and patient safety, points out that complex combination of technology, processes and human interactions may be of higher benefits on one hand but on the other it may generate an inevitable risk of adverse events [4].

While Cometto MC, et al. [3] assumed that patient safety comprehends organizational, clinical and personnel associated factors and involves various actors and specialties; for WHO [4] it not only depends on processes and human interactions but also on technology integration and effects, benefits and adverse events assessment.

Adverse events and medical errors are the main focus of patient safety research which, as stated by Frize, et al. [5] remains an unsolved issue in hospital settings; and is remarked by increasing technological progress.

Boivin, et al. [6] referred that the most relevant factors to analyze in technology evaluation are those associated to patient and health personnel. Hence safety it is a concept to take into account ever since the design of systems and methodologies for technology assessment and management.

Health technology management, and particularly technology assessment is assumed as a priority for Cuban Health System; and safety is a key component within hospital accreditation standards. These two connected themes are included in various Research Technology and Innovation national programs that were established between $2015 \mathrm{y}$ 2016 [7].

This work aims to explore the relevance of Health Technology Management for safety and quality in health care.

\section{Methodology}

It was designed a descriptive and exploratory research; health technology management, safety and quality of health care were the variables under study. The strategy adopted was as follows:

a) It was established a semi-structured interview with the following questions:
What influence do you consider that health technology has on health environment safety?; According to your experience, what factors are essential in technology and safety relation?; What are the challenges that health technology management faces in assuring a better care environment?

b) The interview was administered to professionals from three health specialties (medicine, nursing and health technology); these specialists are related to both clinical and care and academic settings.

c) There were identified the main variables pointed out by interviewees about health technology management, and its influence on safety and quality of care

d) It was assessed the scientific relevance of such topics based on publications analysis. For that purpose it was established a search on Scielo y Sciencedirect databases that was filtered by location of the terms abstract, title or keywords; limit of year or type of document was set. The selected documents were processed with the support of Endnote bibliographic manager and VOsViewer software for co-word analysis.

\section{Results}

Table 1 showed specialists' perceptions according to the three main questions of the interview, the influence of health technology on patient safety and quality of care, the main factors conditioning this influence and the challenges to face in this context.

The most relevant variables that were identified in the interviews turned to be: safety; human error; adverse event; risks, quality; health technology assessment; technology use; innovation; performance; skills and knowledge. Meanwhile safety was particularly centered in patient safety.

Thanks to this terms search, there were initially recovered 895 papers; when eliminating duplicates, the list was reduced to 840 documents and finally there were selected 77 documents ( 29 from Scielo and 48 from Science direct database). The selection of papers depended on direct relation to the current study and it was supported by comprehensive analysis of abstract and key words.

Table 2 compiled the common variables extracted from interviews and its presence in research documents on health technology management, health assessment and patient safety. 


\begin{tabular}{|c|c|}
\hline $\begin{array}{l}\text { Specialist/ Professional } \\
\text { background }\end{array}$ & Perceptions \\
\hline \multirow{3}{*}{$\begin{array}{l}\text { Medical doctor specialized in } \\
\text { Surgery Professional experience: } \\
24 \text { years; Researcher of an } \\
\text { innovation project on evaluation } \\
\text { of techniques and procedures } \\
\text { for minimum access surgery. } \\
\text { Surgeon of a clinical and surgical } \\
\text { hospital }\end{array}$} & $\begin{array}{l}\text { Influence: Technology acquisition in Cuba is mainly conditioned by obtained benefits for } \\
\text { patient's health already proved in other environments. }\end{array}$ \\
\hline & $\begin{array}{l}\text { Main factors: There are two generally used criteria for that purpose: impact and } \\
\text { advances demonstrated by that technology. Limited access and financial capacity to buy } \\
\text { such devices, enforce the thorough analysis of health care effectiveness by means of what } \\
\text { adverse events it may generate to a certain group of patients together with ethical issues } \\
\text { accomplishments- }\end{array}$ \\
\hline & $\begin{array}{l}\text { Challenges: Creativity and innovation should be enhanced to be the source to minimize } \\
\text { technology importation and boost research on the assessment of those technology } \\
\text { innovations effectiveness not only from an economic point of view but from safety related } \\
\text { criteria as well }\end{array}$ \\
\hline \multirow{3}{*}{$\begin{array}{l}\text { Nurse, Master of Science } \\
\text { in Obstetrics Emergency. } \\
\text { Professional experience: } 46 \\
\text { years, main researcher of a } \\
\text { project patient safety and quality } \\
\text { of nursing care }\end{array}$} & $\begin{array}{c}\text { Influence: when technology is involved nursing personnel should reinforce all needed } \\
\text { precautions when preparing patient, physically and psychologically speaking for a } \\
\text { surgical intervention or clinical treatment. }\end{array}$ \\
\hline & $\begin{array}{l}\text { Main factors: in nursing practice could be frequent that unwanted outcomes may occur } \\
\text { due to appropriated disinfection of hands, and of clinical and care environment, lack } \\
\text { of knowledge and skills on managing the technology or inadequate preparation of the } \\
\text { patient to face the treatment }\end{array}$ \\
\hline & $\begin{array}{l}\text { Challenges: ensuring proper communication with patients, monitoring personnel } \\
\text { performance, skills and risks awareness of technology use are key challenges in safety } \\
\text { management. }\end{array}$ \\
\hline \multirow{3}{*}{$\begin{array}{l}\text { Nurse, PhD Professional } \\
\text { experience: } 20 \text { years, second } \\
\text { researcher of a project patient } \\
\text { safety and quality of nursing care }\end{array}$} & $\begin{array}{l}\text { Influence: To not be aware of clinical and psychological condition of the patient and not } \\
\text { be accordingly prepared (nursing skills and knowledge are essential for that matter) } \\
\text { before being treated with certain equipment, could turn into false measure or result }\end{array}$ \\
\hline & $\begin{array}{l}\text { Main factors: cost- benefits analysis is a key criterion when evaluating the use of } \\
\text { certain technologies that is certain equipment beyond beneficial may held higher costs } \\
\text { associated to risks to patient safety due to specific physical conditions or dysfunctions. }\end{array}$ \\
\hline & $\begin{array}{l}\text { Challenges: the need of comprehensive cost-benefits analysis involving risks and adverse } \\
\text { events resulting from using certain devices on patients with special physical conditions } \\
\text { or dysfunction }\end{array}$ \\
\hline \multirow{3}{*}{$\begin{array}{l}\text { Specialist in Optics and } \\
\text { Optometry Professional } \\
\text { experience: five years, main } \\
\text { researcher of a project on } \\
\text { the implementation of a web } \\
\text { based software for optics } \\
\text { and optometry knowledge } \\
\text { management }\end{array}$} & $\begin{array}{l}\text { Influence: the use of ophthalmic equipment requires basic disinfection tasks, availability } \\
\text { and quality of protection devices so as to guarantee hygiene and safety for patients and } \\
\text { care personnel }\end{array}$ \\
\hline & $\begin{array}{l}\text { Main factors: personnel work and skills management is important to support proper use } \\
\text { of the equipment, minimize or avoid human errors. Metrology system to assure reliable } \\
\text { results of the equipment and stress management associated to care environment are also } \\
\text { essential to deliver safe service to patients. }\end{array}$ \\
\hline & $\begin{array}{l}\text { Challenges: to connect technology management with hospital planning system } \\
\text { (consultation time, care standards, tests scheduling); the accomplishment of clinical } \\
\text { practice guidelines and protocols integrated with technology use when evaluating and } \\
\text { improving the quality of care processes; managing continuous personnel training not } \\
\text { only on clinical techniques and practices but also on the use of the equipment acquired } \\
\text { and introduced in the health setting; maintenance, innovation and upgrading of idle } \\
\text { devices' patterns, specifications and installation software }\end{array}$ \\
\hline
\end{tabular}

Table 1: Brief research analysis of Health Technology assessment and its influence on safety and quality of health care. 


\begin{tabular}{|c|c|c|}
\hline Variable & Sciencedirect & Scielo \\
\hline Keywords & $\begin{array}{l}\text { Technology; Technology and Health } \\
\text { technology assessment; Safety and patient } \\
\text { safety; Effectiveness; Technology use; } \\
\text { Error; Communication; Medical devices; } \\
\text { Risk; Information technology and health } \\
\text { information technology; safety management; } \\
\text { Innovation; Medical error; Health technology } \\
\text { management; Evidence based medicine }\end{array}$ & $\begin{array}{c}\text { Technology use and evaluation; } \\
\text { Biomedical technology; Patient } \\
\text { safety; Nursing; Intensive Care Units; } \\
\text { E-nursing; Error; Risk; Training; } \\
\text { Nursing care }\end{array}$ \\
\hline Most frequent documents & Research article; Book section & Research article \\
\hline $\begin{array}{c}\text { Main publication year (years with } \\
4 \text { or more publications) }\end{array}$ & 2007 (4); 2009 (4); 2013 (5); 2020 (5) & 2016 (4); 2017 (4); $2018(4) ; 2019(7)$ \\
\hline
\end{tabular}

Table 2: Theme analysis according to publications recovered.

Figure 1 shows the co-word map referring the highest links and relations among main themes around technology

and safety, as well as time evolution of such topics.

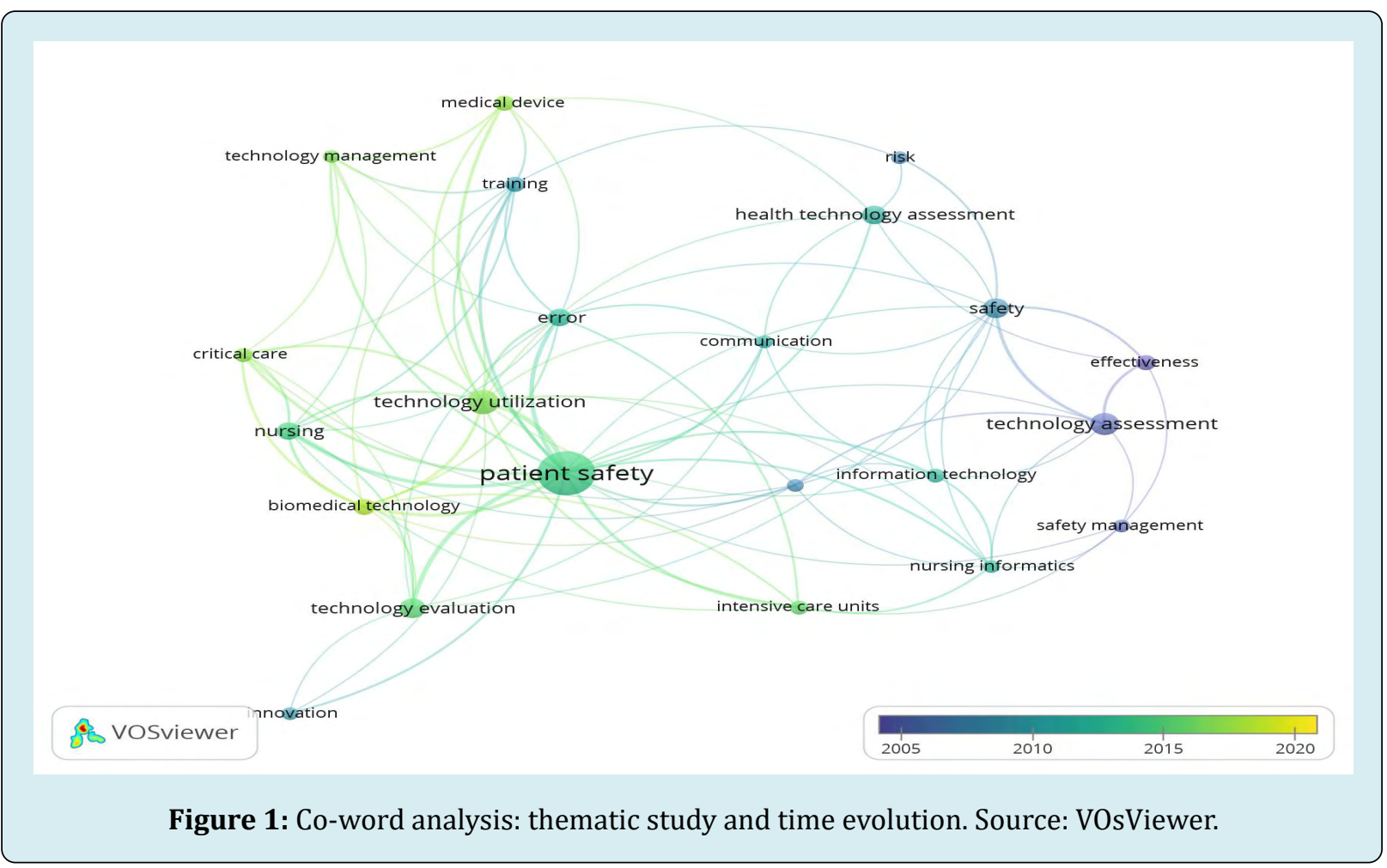

\section{Four Clusters Were Identified:}

1. Communication; effectiveness; technology and health technology assessment; information technology; medical errors; nursing informatics; risks; safety and safety management

2. Biomedical technology; critical care; intensive care units; nursing; technology utilization

3. Error; medical device; technology management; training

4. Innovación; patients safety; technology evaluation
5. Co-word map and clusters confirm previous analysis around the connection of health technology and patient safety, and the consideration of related factors like human errors, training, innovation and environment specifics.

\section{Discussion}

The first interviewee's opinion leaded to the fact that regulatory system in Cuba (directed by State Center for Drugs 
and Medical Devices Control, CECMED) is rigorous about: establishing medical equipment and devices that require functional evaluation; gathering information on equipment's providers, manufacturers and importers; and developing a methodology to certify the equipment that is devised and manufactured through internal research development and innovation activities [8].

The study of adverse events is highly associated to health technology management and assessment [9], and is a key variable in clinical effectiveness analysis, which is one of three pillars of health technology cost-effectiveness [10]. Very related with the nurse's viewpoint about the impact of clinical and psychological condition of the patient on the benefits or adverse events that may cause the equipment used on the intervention, in 2011 it was reported that statistics in Spain showed that almost $25 \%$ of patients with pacemaker might suffer from arrhythmia and heart failure within three years; this statement leaded to scientists questioning about the effectiveness of modifying the location to implant the pacemaker to minimize adverse events while maximizing heart stimulation [11].

Interactions among patients, nursing personnel and technology use in care delivery are supported by key principles in nursing practice, as referred in publications that is: aiding patients to preserve their personality, to recover their wellbeing as well as preventing them from injuries, external agents or diseases [12]. Additionally, nursing practice is challenged by performance improvement mainly based on skills training, as it may prevent adverse event [13].

When consulting main concepts and theories on quality of nursing service, patient safety outstands as a key issue, being defined as appropriate, personalized, humanized, continuous and efficient care, which is delivered according to standards set to guarantee responsible and qualified professional practice and thus assuring patient and health personnel' satisfaction [12-14].

Now, about error being a consequence of technology misuse or failed implementation, the situation depicted by optic and optometry specialist, was coincident with Dr. Leape statement: human error is the result of systems, tasks and process deficiently designed. This underlies the need to improve health technology design and to properly apply engineering principles when devising process and tasks with the aim of reducing error probability [15].

According to Ruiz Ibáñez, et al. [16] the interaction between professional education, clinical process, organizational structure, human behavior and public policy may condition risks occurrence related to biomedical technology use and medical practice. In fact the author conducted a similar study to that of this work, based on health professionals' perceptions about educational and professional experiences concerning patient safety, management programs implementation, security coordination and technology users 'role (health personnel, patients and relatives) on formulation and development of safety based initiatives.

Research analysis confirmed the relevance of the topics aroused from interviews and reveals interesting perspectives such as technology evaluation mainly centered in costeffectiveness and safety; utilization and design impact in errors and advent events occurrence [17]; and required training programs for its development [18].

Another identified trend in scientific study was the increasing design and implementation of information technology to improve quality of care processes, personnel communication and minimizing medication errors $[19,20]$. Gutiérrez Martínez, et al. [21] highlighted the impact of disruptive technologies on medicine up to 2030 and the future predominance of anonymous, structured and safe systems of collection, storage, processing and analysis of higher data volumes consequently generated from information technologies innovations.

Prevalence of original articles over other types of documents proved how relevant is health technology and safety as a research field. The number of articles published during the last ten years resulted to be $48 \%$ out of the total documents reviewed, which might suppose this theme stability and consolidation.

Figure 1 highlighted out the main subjects published between 2015 and 2020: patient safety, technology management and use, biomedical equipment development, information technology for medical practice and applications in intensive care units and nursing services. Then these are supposedly the most researched areas within health technology management.

This work did not cover other opinions from managers, decision makers, researchers or a higher sample of specialists from other health care institutions; nor revealed in-depth scientific study based on other bibliometric analysis. These facts were the main limitations of the study

\section{Conclusions}

Health technology is indeed a factor to take into account for patient safety and quality of care management. Relatedly, human error, innovation, technology use and assessment may condition clinical and therapeutic practice and at the same time could generate risks for patients, health personnel 
and care environment

This topic proves to be of interest not only for health practitioners, decision makers but for researchers as well. The last statement is supported by brief scientific review, that pointed out some relevant ideas: 1) medical technology implementation surely impact on occurrence of adverse events or organizational failures (care service planning and skills management); and 2) innovations on information technology are focusing on assuring safer clinical environment, better communication between personnel and patients and supporting evidence based medicine practice so as to reduce risks and improve efficiency of care and administrative process.

Future directions for this researcher point out to study health technology and its correlation to safety and quality management from theoretical, methodological and practical viewpoints.

Acknowledgements: the author wants to acknowledge the interviewed professionals that authorize the use of its opinions for this study.

\section{References}

1. Lizcano Jaramillo PA, Camacho Cogollo JE (2019) Evaluación de Tecnologías en Salud: Un enfoque hospitalario para la incorporación de dispositivos médicos. Revista Mexicana de Ingeniería Biomédica 40(3): 1-8.

2. Paredes Ojeda RV (2019) Tecnología de la salud: su gestión e innovación. Revista Cubana de Tecnología de la Salud 10(4): 1.

3. Cometto MC, Gómez PF, Dal Sasso GT, Zárate RA, De Bortoli SH, et al. (2011) Enfermería y seguridad de los pacientes. 1st (Edn.), Organización Panamericana de la Salud Washington, USA, pp: 1-17.

4. Organización Mundial de la Salud (2001) Seguridad del paciente. La investigación en seguridad del paciente. Ginebra: OMS.

5. Frize M, Easty A, Polisena J, Trbovich P, Iadanza E, et al. (2020) Patient safety revisited. In: Iadanza E, et al. (Eds.), In: Clinical Engineering Handbook. $2^{\text {nd }}$ (Edn.), Academic Press pp: 330-334.

6. Boivin A, Currie K, Fervers B, Gracia J, James M, et al. (2010) Patient and public involvement in clinical guidelines: international experiences and future perspectives. Qual Saf Health Care 19(5): e22.
7. Pérez NR, Pérez CV, Trujillo NM, Suárez IM, Torres EM, et al. (2018) Ciencia e innovación tecnológica en la salud en Cuba: resultados en problemas seleccionados. Revista Panamericana de Salud Pública 42(32): e32.

8. Centro para el Control Estatal de Medicamentos, Equipos y Dispositivos Médicos (CECMED) (2018) Ámbito Regulador: Lista de equipos y dispositivos médicos que requieren evaluación funcional de muestras. XIX (00311). La Habana: Edición ordinaria.

9. Duarte HGG, Reyes MXR, Alfonso JF (2017) Búsqueda, evaluación y síntesis de la evidencia de efectividad y seguridad en evaluaciones de tecnología: manual metodológico.

10. Pinzón MRC (2019) Los Pilares de Costo-Efectividad: Una guía práctica para tomar decisiones costo-efectivas sobre nuevas tecnologías de la salud. Revista Cubana de Tecnología de la Salud 10(3): 97-103.

11. Sociedad Española de Cardiología (2011) Noticias cardiología.

12. Ribeiro GDAR, Silva RCD, Ferreira MDA (2016) Tecnologias na terapia intensiva: causas dos eventos adversos e implicações para a Enfermagem. Rev Bras Enferm 69(5): 972-980.

13. Andrade BRPD, Barros FDM, Lúcio HFAD, Faria Campos J, Silva RCD, et al. (2019) Training of intensive care nurses to handle continuous hemodialysis: a latent condition for safety. Rev Bras Enferm 72(S1): 105-113.

14. Strudwick G, Reisdorfer E, Warnock C, Kalia K, Sulkers H, et al. (2018) Factors associated with barcode medication administration technology that contribute to patient safety: an integrative review. Journal of nursing care quality 33(1): 79-85.

15. Cernadas JC (2018) Abordaje y la prevención de errores que ocurren en el cuidado de los recién nacidos. Organización Panamericana de la Salud. Centro Latinoamericano de Perinatología, Salud de la Mujer y Reproductiva, Washington DC, USA pp: 1606.

16. Ruiz Ibañez C, Franco A, Mejia Hoyos H, Fajardo R (2010) Perspectivas en seguridad del paciente: entrevista con líderes colombianos. Rev Ing Bioméd 4(8): 10-21.

17. Mason JJ, Roberts Turner R, Amendola V, Sill AM, Hinds PS, et al. (2014) Patient Safety, Error Reduction, and Pediatric Nurses' Perceptions of Smart Pump Technology. Journal of Pediatric Nursing 29(2): 143-151.

18. Arias D, Camacho JE, Osorno J (2016) Mejora de habilidades en la seguridad del paciente implementando 
una estrategia de entrenamiento en el personal asistencial. Rev ing biomed 10(20): 21-25.

19. Fong A, Hettinger AZ, Miller KE, Ratwani RM (2020) Human factor approaches to understand health information technology impacts on patient safety. In: Iadanza E, et al. (Eds.), In: Clinical Engineering Handbook. $2^{\text {nd }}$ (Edn.), Washington DC, Academic Press, USA pp: 876-880.
20. Ferreira AMD, Oliveira JLCD, Camillo NRS, Reis GAXD, Évora YDM, et al. (2019) Percepções dos profissionais de enfermagem acerca do uso da informatização para segurança do paciente. Rev Gaúcha Enferm 40: 1-8.

21. Martínez JAG, Febles AE (2019) Las tecnologías disruptivas y su aplicación en la medicina, una visión al 2030. Revista Cubana de Salud Pública 45(4): 1-16. 